the spectacle of public punishment, public humiliation as revenge, and the specifically feminine figure of the 'sexual collaborator'.

Re-reading Leaving Beirut in 2007, one is struck by its enduring relevance. In an early chapter, when the narrator returns to Beirut, she reflects on her own discomfort with the way that memory of the war had been paved over by new concrete and restaurants. Recalling Mme Nomy's lesson to forgive and forget, Ghoussoub questions her malaise with Lebanon's apparent amnesia, asking 'Can one forget and learn lessons for the future? Is there a way to forget - to live, laugh, make love, bring up new babies and create - without once having to ask: "And why would it not start all over again?"' (p. 35). Today there is no comforting answer to Ghoussoub's questions, with Lebanon once again on the verge of collapse into hauntingly similar violence. This insight emerges in relation to the current climate in the United States as well. In her musings on the similarities between the Stalinist purges and McCarthyite witch-hunts, Ghoussoub observes that the 'exacerbated nationalism' in which both were rooted 'went hand in hand with an obsession with security, meaning that any thinking that did not fit absolutely with the dominant thought was to be eradicated.... the spirit behind these purges is a reminder that we are not immune to the re-emergence of times when heroes and traitors proliferate' ( $p .135)$.

It is this reminder that lingers. The closing chapter, an essay addressed directly to Mme Nomy, revisits the questions Ghoussoub has raised by reflecting on the possibilities for justice. In the end, Mme Nomy's lesson is transformed to a much more complex one, where vengeance and justice may be decoupled, but where there are no simple paths to reconciliation and coexistence. Ghoussoub leaves us with no answers, but with the sense that amnesia is not necessary to reconciliation, nor are revenge and retribution inevitable, and with the hope that a movement away from both vengeance and forgetting may lead to a grey space of reparation, of coexistence, and of new ways to be human.

doi:10.1057/palgrave.fr. 9400399

Lara Deeb

\title{
Muslim women activists in North America: speaking for ourselves
}

Katherine Bullock, editor; University of Texas Press, Austin, Texas, USA, 2005, 237p, ISBN 0-292-70666-9, \$50 (Hbk), \$22.95 (Pbk)

Bullock states the aims of this (post-9/11) book as: to make non-Muslims aware of the amount of activism undertaken by Muslim women '... not in spite of their religion, but because of it' ( $p$. ix); to counter negative stereotypes and provide 
role models for an 'ultra-marginalized group' ( $p$. xviii), and '... to open a channel for constructive dialogue between mainstream society and the nowmaligned Muslim community' ( $p$. xviii).

The eighteen chapters in the book are accounts by Muslim women of their involvement in various forms of activism. All live in Canada or the USA, but differ in age, country of origin, ethnicity, and whether Muslim-born or converts. ${ }^{1}$ Notwithstanding this diversity, the similarities between the authors are striking because of their intense commitment to Islam and their conviction that: 1 . gender equality is a Muslim tenet; 2 . activism is a religious requirement, and 3 . da'wa (spreading the news about Islam) is obligatory.

In terms of gender equality, the book contains some powerful descriptions of the writers' (sometimes painful) struggles with 'traditional' Muslim men and women. It also praises western attitudes to religious freedom. Barazangi dismisses 'predominantly male rhetoric about ... "Western, secular immorality", or ... "imperial, capitalist injustice"' (p. 4), saying: 'Without any doubt, I had more freedom of movement [in the USA] than when I was in Saudi Arabia, more leverage in defying social customs than when I lived in Syria, and more access to Islamic literary sources than what was available in either country' (p. 9).

Rahman defines activism as a religious requirement: '...the linkage of faith with doing righteous deeds is a recurring theme within the Qur'an ... it is not enough to just "have faith" ... but this faith must be translated into action by the performance of righteous deeds...' (pp. 135-136). Whatever term is used to describe the work of the contributors to this book - activism/volunteerism/good works - there is no denying the magnitude of their achievements. By any standards, these women are 'high flyers' with impressive records of attainment. And many of them have combined this with marriage, motherhood (and, indeed, grand-motherhood) as well as travel to various parts of the world, including such war zones as Bosnia and Palestine/Israel. This has entailed both personal and professional sacrifice: Mustapha - a talented pianist - stopped playing because 'certain musical instruments are questionable in Islam' (p. 121), simultaneously restricting her social relationships to Muslims because: 'All Muslims must struggle to elevate the socio-political status of Islam and thus its citizens worldwide' (p. 127); Beshir chose motherhood - '...the best job in the world' (p. 27) - over practising medicine.

This level of commitment to a religious belief (especially when combined with da'wa) verges on the incomprehensible to many of us socialized into secular ideals, including the belief that diversity and inter-cultural/ethnic/religious mixing are positive aspects of post-modern societies. For a striking aspect of this book is that most of its contributors focus their attention on Islam, Muslims and Muslim communities, rather than on causes that cut across boundaries in wider society. Indeed, many writers became involved in activism because they were
1 The countries of origin include Afghanistan, Australia, the Caribbean, Egypt, Pakistan, Palestine, South Africa and Syria. The ethnic heritage of those born in North

America includes

African,

Anglo-Saxon, Caribbean, Egyptian, English-German and Palestinian-Latino parentage. 
2 Siddiqui explains Muslims' lack of engagement with wider society as follows: 'It is the fear of losing our faith and being assimilated that paralyses Muslims from getting involved in the mainstream community and to work towards improving society in general' (p. 190). determined to maintain an Islamic identity in secular societies and: '... [to] resist the powerful, centripetal force of assimilation' (Bullock: p. xv). This attitude influences both the private and public spheres. Shamma states: 'One of the most important jobs of Muslim parents is to immerse their children in an Islamic environment. ... We did whatever was necessary to make sure our children had good Muslim friends. ... We made friends with people because they had children who practiced Islamic behaviour' (pp. 170-171). And in work with secular or interfaith institutions, furthering the cause of Islam and Muslims is prioritized; Farooqi says: 'I believe forming Muslim clubs is an excellent way to spread the message of Islam ... and to spread the word is our job' (p. 77) and Rahman suggests: '.. like bricks in a wall, believers surround, support, and strengthen each other to create a strong unified barrier to external forces' (p. 138). She emphasizes the importance of: '.. working together to educate the larger community about Islam, our beliefs and practices, as well as to work within the various systems to accommodate ... Islamic practices' (p. 139).

This book provides an important counterbalance to stereotypes of Islam as a violent religion that renders women subservient to men. Whether it has achieved its aim of opening dialogue between mainstream societies and Muslims is more debatable. For only one writer, Shahina Siddiqui, adopts an inclusive approach: 'I believe that we cannot be isolationist in our activism since the world is one, humanity is one, and what affects others affects me as well' (p. 190). ${ }^{2}$ Despite their impressive work, most of the other writers seem to define activism in ways that exclude non-Muslims and prohibit the two-way interaction that is arguably a pre-requisite of dialogue - and this is surely a loss for us all.

Marie Macey

doi:10.1057/palgrave.fr. 9400390

\section{Feminist politics, activism and vision: local and global challenges}

Luciana Ricciutelli, Angela Miles and Margaret McFadden (editors); Zed Books, London and New York, 2005, 320p, ISBN 1-84277-350-X, £55.00 (Hbk); ISBN 1-84277-351-8, £17.95 (Pbk)

Luciana Ricciutelli, Angela Miles and Margaret McFadden have compiled a refreshingly diverse array of papers from twenty activists, scholars and policymakers who attempt to answer the question of how contemporary feminism can sustain its efforts in the face of 'neo-liberal globalization and religious fundamentalisms' (p. 9). Accessible to a range of readers, this project contributes to the dynamic debates around whether women's activism and its 